\title{
せん断応力と引張応力が作用する 鋼材の延性破壊メカニズムの解明に関する研究
}

\author{
篠原 一輝 1 - 賈 良㺵 2 -加藤 弘務 3 - 葛 漢涁 4 \\ 1学生会員 名城大学 理工学部建設システム工学科 \\ （干468-8502 愛知県名古屋市天白区塩釜口1-501） \\ E-mail:110425157@ccalumni.meijo-u.ac.jp \\ 2ポスドク研究員 名城大学自然災害リスク軽減研究センター \\ （干468-8502 愛知県名古屋市天白区塩釜口1-501） \\ 3学生会員 名城大学大学院 理工学研究科建設システム工学専攻 \\ （干468-8502 愛知県名古屋市天白区塩釜口1-501） \\ 4フェロー 名城大学教授 理工学部社会基盤デザイン工学科 \\ （干468-8502 愛知県名古屋市天白区塩釜口1-501） \\ E-mail: gehanbin@meijo-u.ac.jp
}

\begin{abstract}
大地震で被災した鋼構造物では，すみ肉溶接や部分溶け込み溶接による接合部における破断がよく見ら れている.そこでは引張応力のみならずせん断応力も作用する場合がある。しかし，引張応力とせん断応 力を受ける鋼部材の延性破壊のメカニズムの解明は進んでいないのが現状である. 本研究では, せん断応 力が鋼材の延性き裂の発生から破断までの挙動にどのような影響を及ぼすかについて調べようしている. また，異なる鋼材の破壊までの塑性吸収エネルギーによる比較を行い，定量的な関係が見られるか検討す ることも目的の一つである.
\end{abstract}

Key Words : ductile fracture,shear stress,tensile stress, monotonic loading, absorbed plastic energy

\section{1. 緒言}

1995年の兵庫県南部地震では，多くの鋼構造物に脆性 的な破壊が生じた。中でも神戸ハーバーウェイP75橋脚 の隅角部においては，鋼橋において初めて脆性的な破壊 モードが確認された ${ }^{1) 3)}$. 特に，溶接部近傍で塑性変形 後の破壊が見られた ${ }^{4}$. 塑性変形過程での脆性的な破壊 は，多軸応力とひずみ集中を受ける接合部などにおいて， まず延性き裂が発生し，そこに応力が集中し延性き裂が 進展して，ある限界サイズに達したとき生じるというこ とが知られている. したがって，地震時の脆性的な破壊 を防止するためには，大きな塑性ひずみを受けた後でも 十分な破壊靶性を有する鋼材を適用することが必要であ ると考えられる.

一方，柱部材は主に圧縮および曲げを受けるのに対し， 梁腹板や隅角部，部分溶け込み溶接断面ではせん断も作 用する場合がある5,6. 特に部分溶け込み溶接断面では図 -1に示すような破壊モードが見られた. ここでは図-2に 示すように引張応力だけでなくせん断応力も作用してい
る.これまでの鋼構造分野における研究では，垂直応力 （引張応力）が支配する状況での破壊実験は数多く行わ れており，文献7)，8)のようなせん断座屈に関する研究 は行われているものの, せん断応力と引張応力が同時に

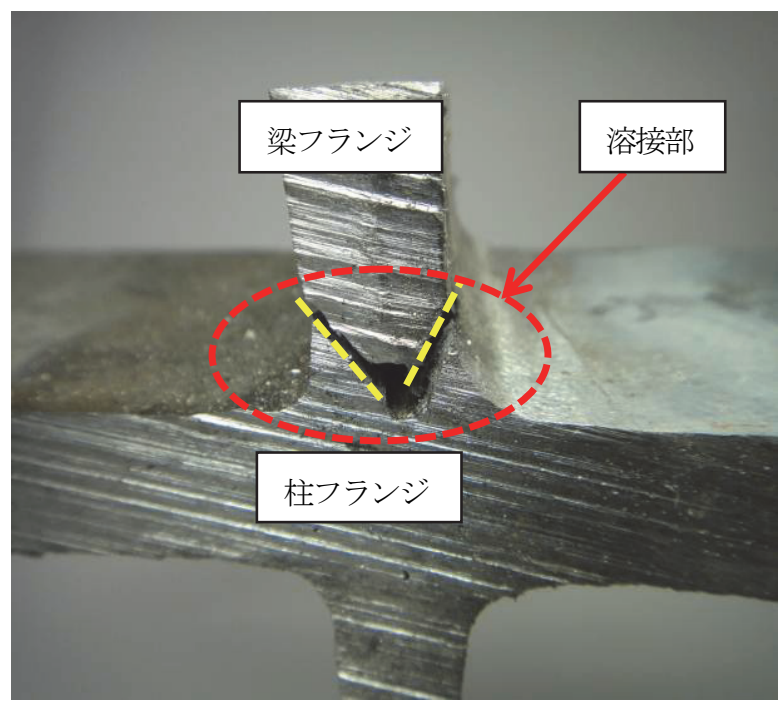

図-1＼cjkstart部分溶け込み溶接断面の破壊モード 
作用する状況での延性破壊に関するメカニズムの解明は 進んでいないのが現状である，そこで本研究では，梁柱 隅角部や部分溶け込み溶接断面に作用寸るせん断応力の 影響を調べる基礎的検討として, せん断応力と引張応力 が同時に作用する状況での鋼材の破壊実験を材料レベル にて行い，破壊までの過程や破断面の状況を実験的に明 らかにし, 複合応力状態下の延性破壊現象を解析的に解 明することを目的としている. 今後, 本研究により得ら れた知見を溶接部材や制震部材の設計に活用していくこ とが期待できる.

そこで今回は単調載荷試験を行い, き裂の発生から破 断までのプロセスや破断面の角度などについて比較検討
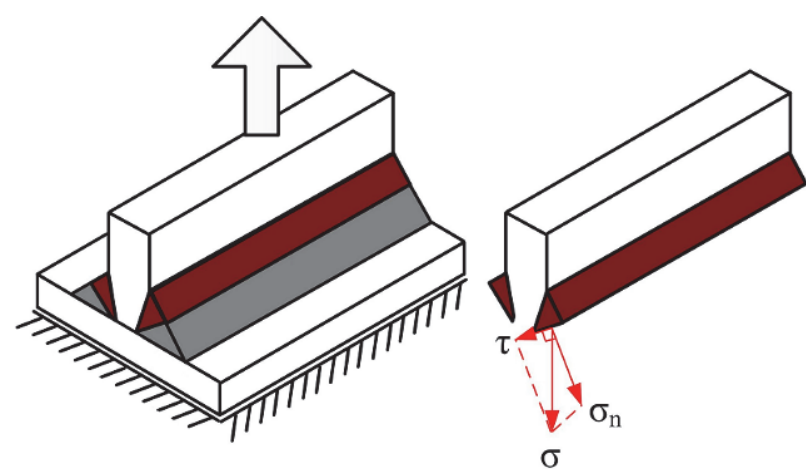

図-2 部分溶け込み溶接断面の応力状態

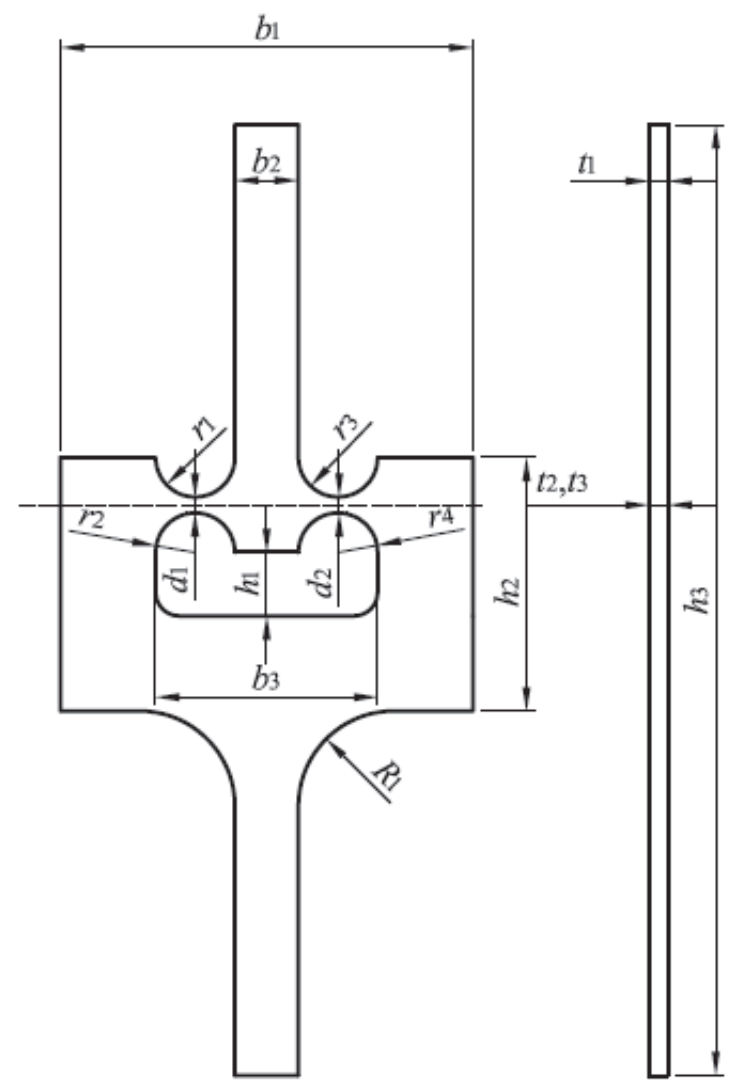

(a) PSシリーズ
を行う。そして，実験から得られた荷重一変位曲線を用 いてエネルギ一吸収量を算出する。 また，延性破壊モデ ルを用いた破壊解析を行う。さらに, SS400, SM490A, SM570の三種類の鋼材を用いて実験を行うため, 鋼種の 違いによる影響を明らかにし，それぞれの材料特性につ いても併せて検討を行う。

\section{2. 実験概要}

ここで，試験片について説明する．三種類の鋼種にそ れぞれ初期状態で純せん断が作用する場合 (Pure Shearシ リーズ，以降PSシリーズと称する），軸力とせん断力 が作用する場合 (Shear and Tension シリーズ, 以降STシ リーズと称する）の二種類を用いての単調引張試験

(Monotonic Tensile Test) を行う。試験片の概要図, 実測 寸法，化学成分および機械的性質をそれぞれ図-3, 表-1, 2，3に示寸. 表-3に示寸機械的性質は実験直前に行った 引張試験の結果（2本の平均値）である.

試験片の設計は，破壊する箇所を特定するためにPS シリーズ, STシリーズ共に $r_{1}=r_{2}=r_{3}=r_{4}=25 \mathrm{~mm} の$ 半径 (設計值) で切り出し, 他の部分より細くすることで断 面積を小さくした. この部分 (以降, 塑性変形部と称寸

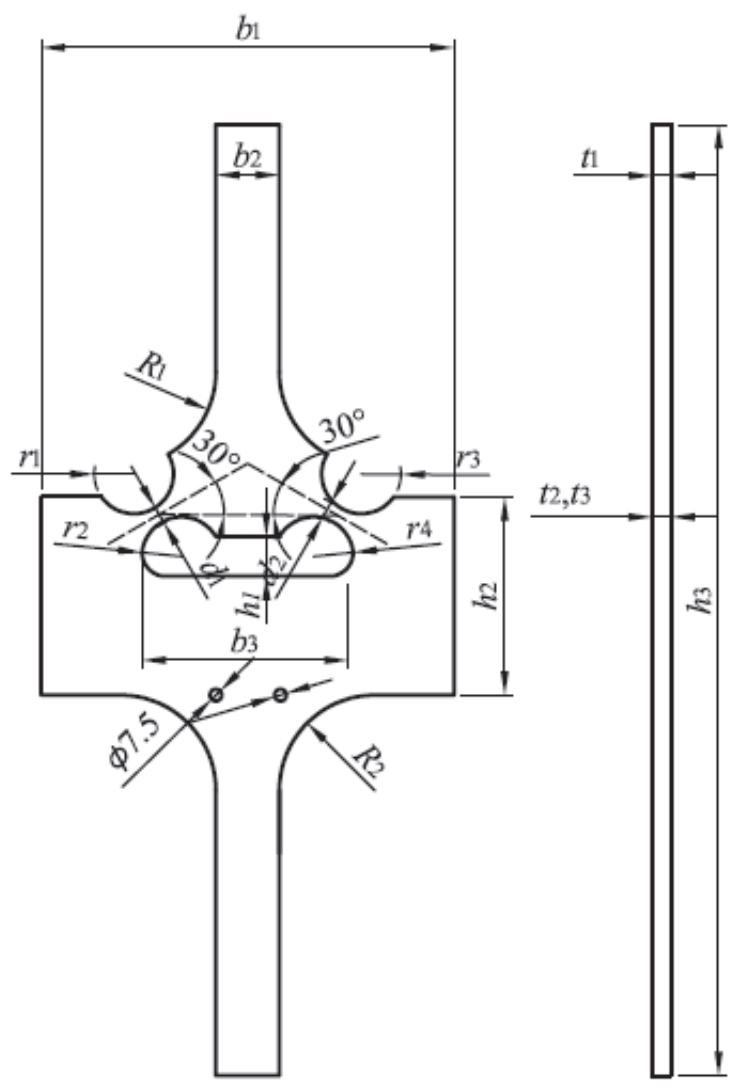

(b) STシリーズ 
表-1 実測寸法 (mm)

\begin{tabular}{|l|c|c|c|c|c|c|c|c|c|c|c|c|c|c|c|c|c|}
\hline \multicolumn{1}{|c|}{ 試験片名 } & $b_{1}$ & $b_{2}$ & $b_{3}$ & $h_{1}$ & $h_{2}$ & $h_{3}$ & $R_{1}$ & $R_{2}$ & $d_{1}$ & $d_{2}$ & $r_{1}$ & $r_{2}$ & $r_{3}$ & $r_{4}$ & $t_{1}$ & $t_{2}$ & $t_{3}$ \\
\hline PS-SS400-M & 40 & 260 & 140 & 40 & 160 & 600 & 60 & & 10.3 & 10.3 & 25.1 & 25.3 & 25.2 & 24.9 & 11.6 & 11.6 & 11.6 \\
\hline PS-SM490-M & 40 & 260 & 140 & 39 & 161 & 600 & 60 & & 10.3 & 10.3 & 25.3 & 24.7 & 25.0 & 24.7 & 11.6 & 11.6 & 11.6 \\
\hline PS-SM570-M & 40 & 260 & 140 & 39 & 160 & 600 & 61 & & 10.2 & 10.2 & 24.8 & 24.7 & 25.0 & 24.7 & 12.0 & 12.0 & 12.0 \\
\hline ST-SS400-M & 40 & 260 & 134 & 30 & 125 & 600 & 60 & 60 & 10.2 & 10.2 & 25.3 & 25.3 & 25.7 & 25.6 & 11.5 & 11.5 & 11.5 \\
\hline ST-SM490-M & 40 & 260 & 132 & 30 & 125 & 600 & 60 & 60 & 10.2 & 10.2 & 24.7 & 24.4 & 25.1 & 25.2 & 11.6 & 11.6 & 11.6 \\
\hline ST-SM570-M & 40 & 260 & 133 & 30 & 125 & 600 & 59 & 60 & 10.2 & 10.2 & 25.3 & 25.1 & 25.8 & 25.4 & 12.0 & 12.0 & 12.0 \\
\hline
\end{tabular}

表-2 化学成分 (\%)

\begin{tabular}{|c|c|c|c|c|c|c|c|c|c|c|}
\hline 鋼種 & $\mathrm{C}$ & $\mathrm{Si}$ & $\mathrm{Mn}$ & $\mathrm{P}$ & $\mathrm{S}$ & $\mathrm{Cu}$ & $\mathrm{Ni}$ & $\mathrm{Cr}$ & $\mathrm{Nb}$ & $\mathrm{V}$ \\
\hline $\mathrm{SS} 400$ & 0.12 & 0.23 & 0.57 & 0.016 & 0.015 & & & & & \\
\hline $\mathrm{SM} 490 \mathrm{~A}$ & 0.1 & 0.25 & 1.41 & 0.016 & 0.004 & & & & 0.012 & 0.001 \\
\hline $\mathrm{SM} 570$ & 0.1 & 0.18 & 1.54 & 0.01 & 0.002 & 0.01 & 0.02 & 0.01 & 0.02 & 0.06 \\
\hline
\end{tabular}

表-3 機械的性質

\begin{tabular}{|c|c|c|c|c|c|}
\hline 鋼種 & $\begin{array}{c}\text { 降伏点 } \\
(\mathrm{MPa})\end{array}$ & $\begin{array}{c}\text { 引張強さ } \\
(\mathrm{MPa})\end{array}$ & $\begin{array}{c}\text { ヤング率 } \\
(\mathrm{GPa})\end{array}$ & $\begin{array}{c}\text { ポアソ } \\
\text { ン比 }\end{array}$ & $\begin{array}{c}\text { 伸び } \\
(\%)\end{array}$ \\
\hline SS400 & 283 & 416 & 204 & 0.29 & 32 \\
\hline SM490A & 351 & 530 & 204 & 0.28 & 24 \\
\hline SM570 & 543 & 643 & 208 & 0.27 & 15 \\
\hline
\end{tabular}
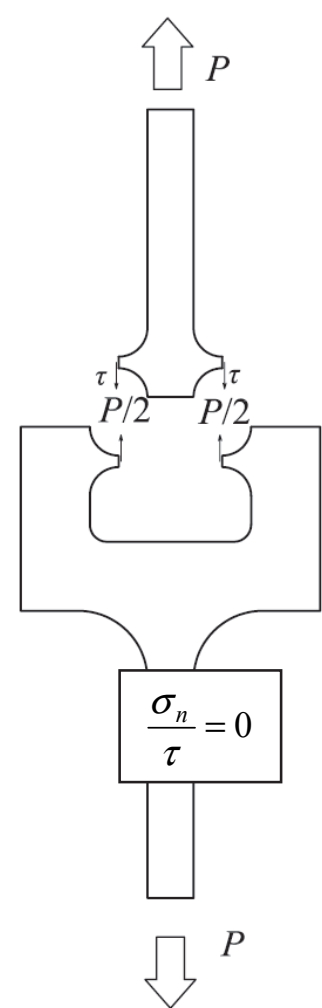

(a) PS シリーズ

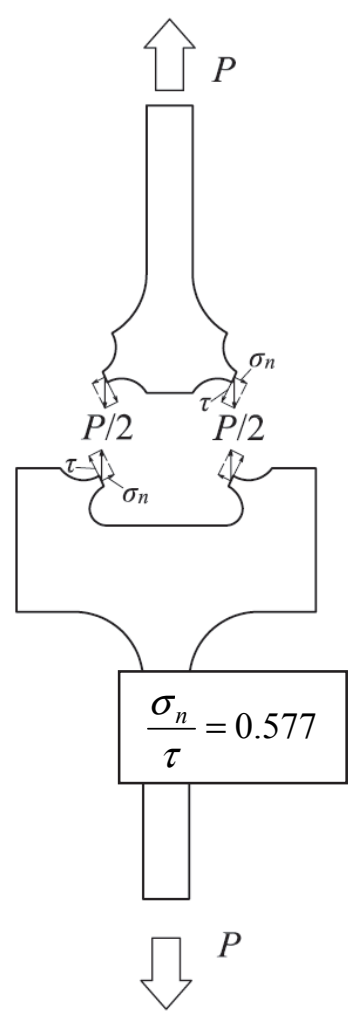

(b) STシリーズ
図-4 試験片に作用寸る応力図

る）が単調引張試験を行った際に塑性化すると想定して いる.また，PSシリーズは載荷軸方向と垂直な方向に 対し塑性変形部が0。になるうに設定し，STシリーズで は載荷軸方向と垂直な方向に対し塑性変形部が $30^{\circ}$ の角

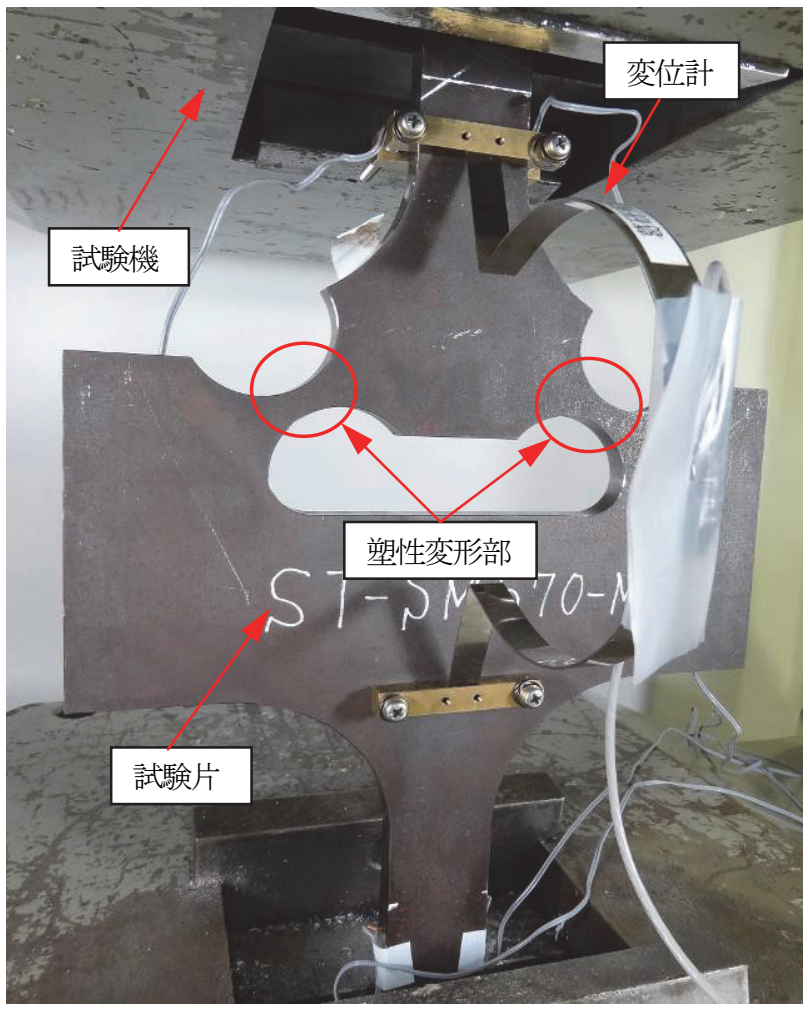

図-5 試験片を設置した状態

度になるように設定した。 そのため，PSシリーズでは， 初期状態において塑性変形部の断面にせん断力のみが 作用し，STシリーズでは塑性変形部に載荷軸方向と垂 直な方向に $30^{\circ}$ の角度を与えることで, 塑性変形部の断 面に対しせん断力と軸力が作用する. 両端に外力 $P$ 載 荷した場合に塑性変形部に作用する応力図と，載荷初 期段階における引張応力 $\sigma_{n}$ とせん断応力 $\tau$ の比 $\sigma_{n} / \tau$ を図 -4に示す. PSシリーズではせん断のみが作用する設計 であるため， $\sigma_{n} / \tau$ の值は0であり，STシリーズでは $30^{\circ}$ の角度が与えてあるため $\sigma_{n} / \tau$ の值は0.577である. なお, STシリーズには変位計を取り付けるための穴（ $\phi 7.5$ mm)をあけている.

実験には，島津万能試験機（以降，試験機とする）を 
用いる．試験片を設置した状態を図-5に示す．試験片の 偏心をできるだけ少なくするためひずみゲージを板厚方 向に4枚貼り，4枚のゲージの䛊差が $10 \%$ 以内になるよう に調整しながら試験片を設置した．試験機の制御は手動 で行い, ひずみゲージ, 変位計, 荷重の出力の值はデー タロガーを通じてパソコンでモニターした．変位計は標 点間距離200 mmのパイ型のものを用いた. 三台のビデ オカメラを用いて実験中の試験片の様子を正面と塑性変 形部の上下から撮影する．載荷は試験片が破断するまで 行い, 載荷速度は準静的であり, 温度は室温で行った。

図-6にSS400，SM490AおよびSM570の三種類の引張試 験片の公称応力一公称ひずみ曲線を示す．図一より，材 料の強度が高くなるほど最大応力は大きくなり，その時 のひずみは小さくなっていることがわかる．また，表-3 に示寸ように全体の伸びは強度が高くなるほど小さくな っている.

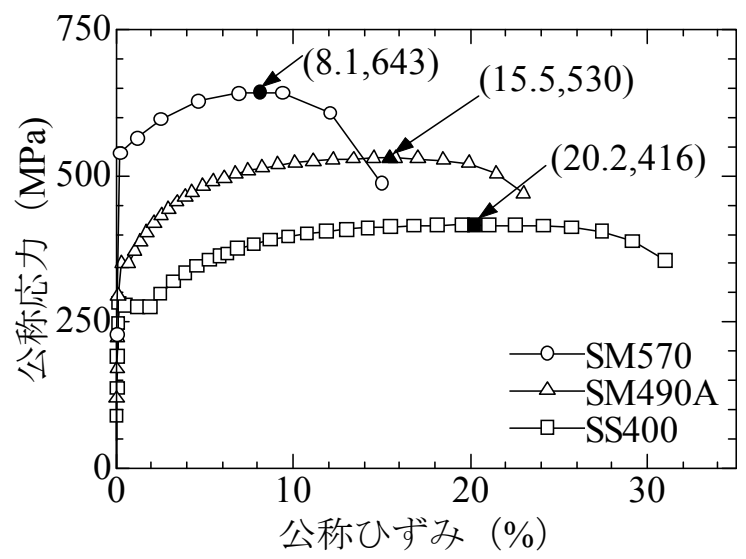

図-6 引張試験の公称応力一公称ひずみ曲線

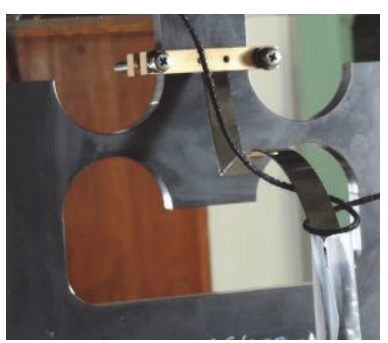

（a）載荷直前

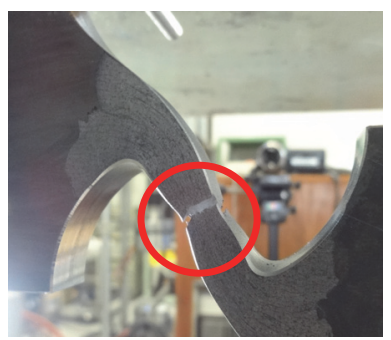

(e) 破断

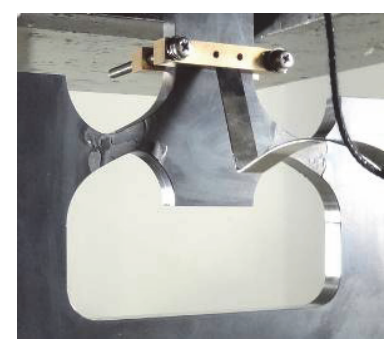

(b) 塑性変形開始

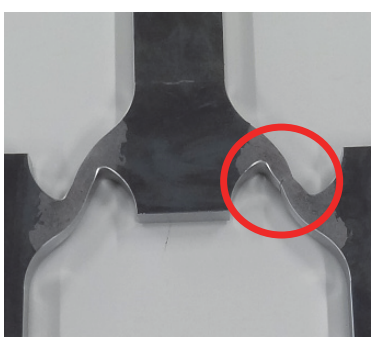

(f) 試験終了

\section{3. 実験結果}

\section{(1) 破壊モード}

ここで，破壊概況と破断面の比較，およびネッキング 後の伸びについて述べる.

\section{a) 破壊概況}

PSシリーズとSTシリーズの破壊過程と走査型電子顕 微鏡 (SEM) により撮影した写真を写真-1, 2に示す. 写真-1，2の (b)，（c)に示すように，塑性変形を受ける 過程では概ね左右対称の変形が見られた。 その後ネッキ ングが片側の塑性変形部の中央で発生し，この部分に変 形が集中し，一気に破断した. 試験片の設計は左右対称 であったが，最終的な破壊モードは左右対称ではなかっ た.これは実測寸法が僅かながら左右対称でなかったこ とと, 載荷軸の僅かな偏心があったことが考えられる. このようにネッキング発生までの塑性変形中では概ね左 右対称であったため, ネッキング発生は僅かな非対称性 などが敏感に影響すると考えられる。また，PSシリー ズでは写真-1の (c) に示すように，塑性変形を受ける過 程で塑性変形部が載荷軸の方向に次第に近づいていき, 塑性変形部の断面は次第にせん断応力より引張応力が支 配する状況になったことが考えられる．写真-1，2の (g) に示すように破断面中央部では，引張破壊に見られる大 きなディンプルとせん断方向に僅かに伸びたディンプル が確認できる． $\sigma_{n} / \tau$ の值が小さいPSシリーズの方が引張 破壊による大きなディンプルが多く確認できる. 写真-1, 2の (h) に示すように破断面縁部でははっきりとせん断方 向が確認でき，また， せん断方向に大きく伸びたディン プルが確認できる.

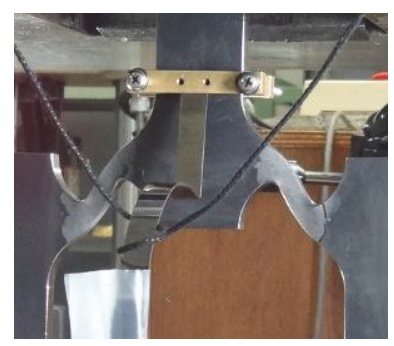

(c) 塑性変形中

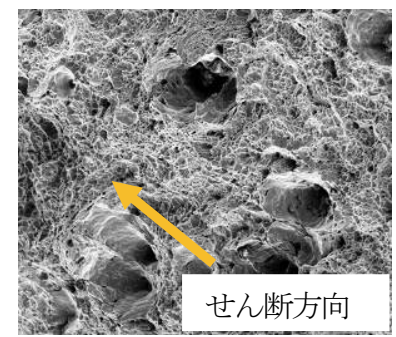

(g) 破断面中央部

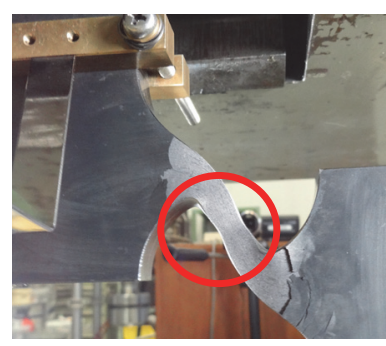

（d）ネッキング発生

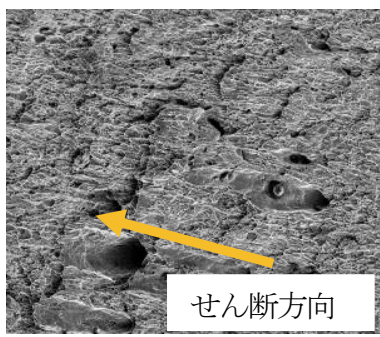

(h) 破断面縁部

写真-1 PS シリーズの破壊過程 


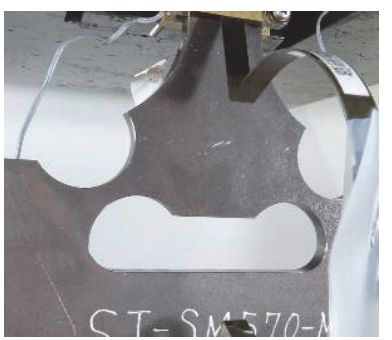

(a) 載荷直前

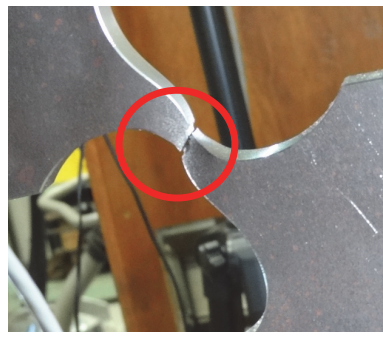

(e) 破断

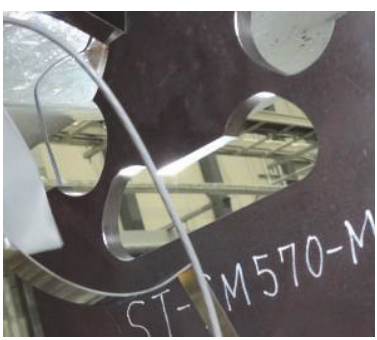

(b) 塑性変形開始

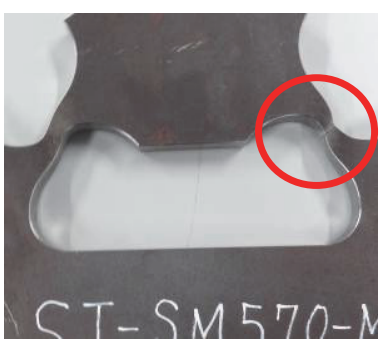

(f) 試験終了

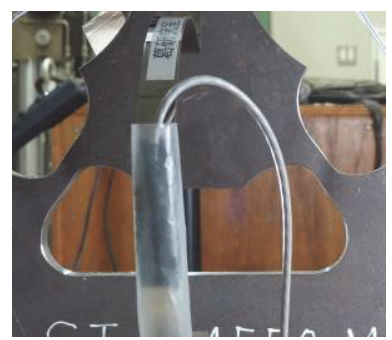

(c) 塑性変形中

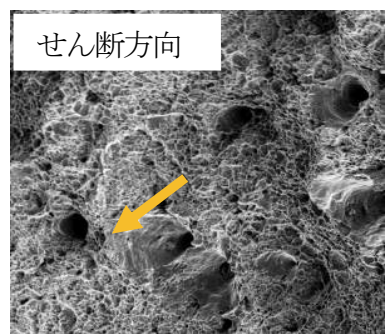

(g) 破断面中央部

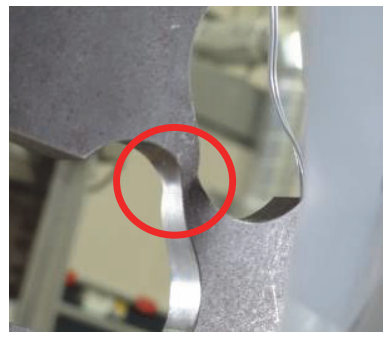

(d) ネッキング発生

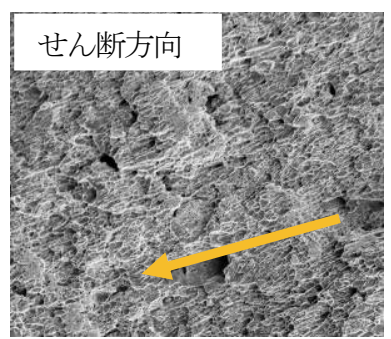

(h) 破断面縁部

写真-2 STシリーズの破壊過程

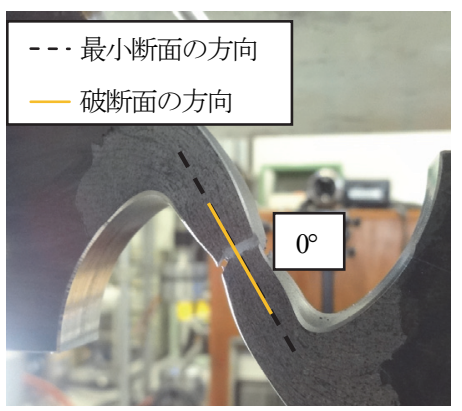

(a) PS-SS400-M

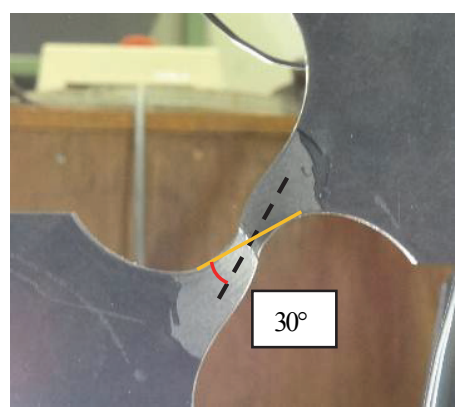

(d) ST-SS400-M

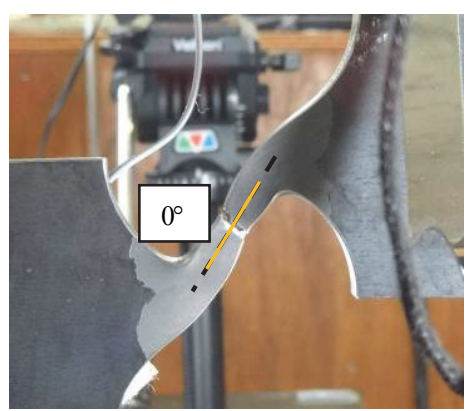

(b) PS-SM490-M

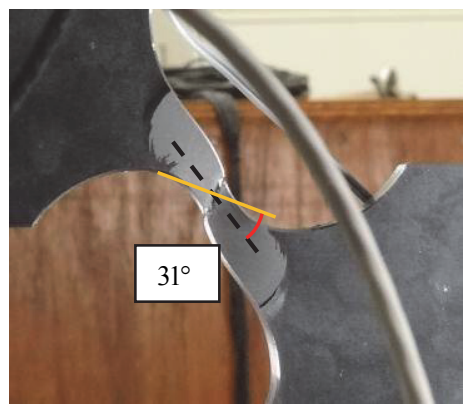

(e) ST-SM490-M

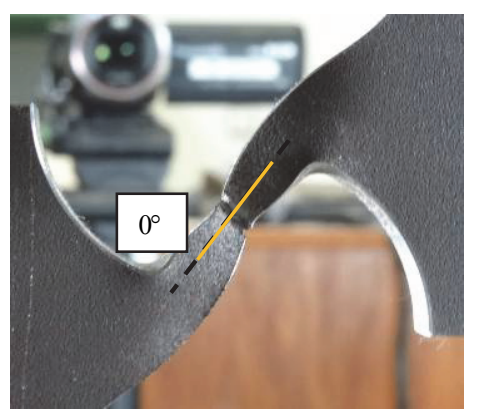

(c) PS-SM570-M

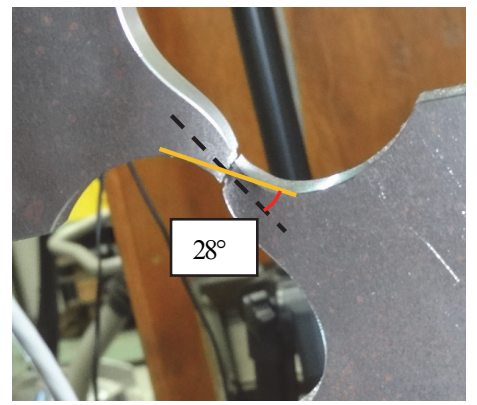

(f) ST-SM570-M

写真-3 破断面の角度の比較

\section{b) 破断面の角度の比較}

一軸の引張試験を行うと，角度 $0^{\circ}$ の破断面（載荷軸方 向に垂直な断面）に加え，角度を持ったせん断破壊面も 生じることがあるが，本研究においては，塑性変形部の 最小断面の方向と破断面の方向との角度を破断面の角度 之定義する. 写真-3に, 各試験片の塑性変形部の最小断 面の方向を黒の破線，破断面の方向を黄色の実線で示す． 試験終了後に計測した破断面の角度と解析により得られ た角度を表-4に示寸．PSシリーズでは $0^{\circ} ，$ STシリーズで は概ね $30^{\circ}$ であった，写真-4のように比較すると，PSシ リーズでは破断直前における塑性変形部の破断面の角度 が一軸の引張試験と同じであるため引張応力が支配して
表-4 破断面の角度の比較

\begin{tabular}{|c|c|c|}
\hline 試験片名 & 実験結果 & 解析結果 \\
\hline PS-SS400-M & $0^{\circ}$ & $2^{\circ}$ \\
\hline PS-SM490-M & $0^{\circ}$ & $0^{\circ}$ \\
\hline PS-SM570-M & $0^{\circ}$ & $0^{\circ}$ \\
\hline ST-SS400-M & $30^{\circ}$ & $29^{\circ}$ \\
\hline ST-SM490-M & $31^{\circ}$ & $29^{\circ}$ \\
\hline ST-SM570-M & $28^{\circ}$ & $28^{\circ}$ \\
\hline
\end{tabular}

いると考えられる。.また，STシリーズでは概ね30の角 度が得られたため引張応力とせん断応力が同時に作用し 


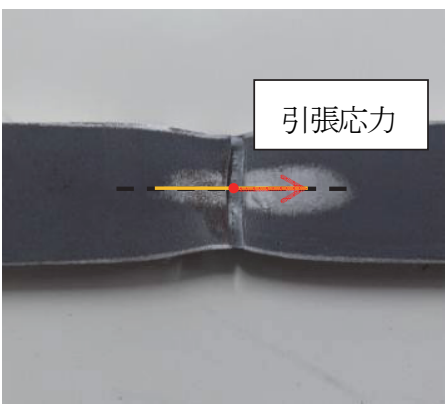

(a) 材料試験

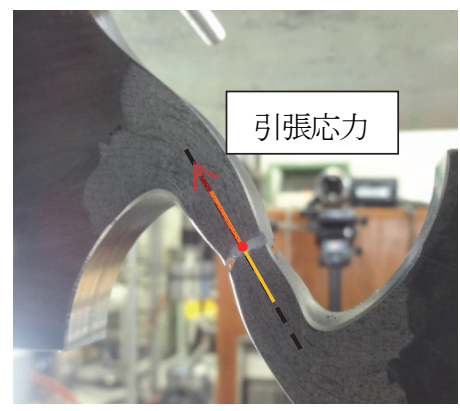

(b) PS シリーズ

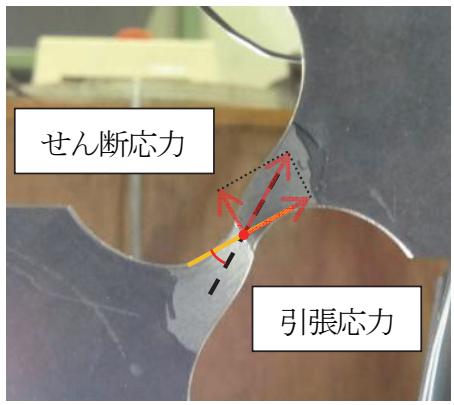

(c) ST シリーズ

写真-4 破断面の角度による応力の解析

表-5ネッキング後の伸び量とその割合

\begin{tabular}{|c|c|c|c|c|}
\hline \multirow{2}{*}{ 鋼種 } & \multicolumn{2}{|c|}{ PS シリーズ } & \multicolumn{2}{c|}{ ST シリーズ } \\
\cline { 2 - 5 } & $\begin{array}{c}\Delta_{n} \\
(\mathrm{~mm})\end{array}$ & $\begin{array}{c}\alpha \\
(\%)\end{array}$ & $\begin{array}{c}\Delta_{n} \\
(\mathrm{~mm})\end{array}$ & $\begin{array}{c}\alpha \\
(\%)\end{array}$ \\
\hline $\mathrm{SS} 400$ & 3.26 & 11.1 & 2.17 & 17.1 \\
\hline $\mathrm{SM} 490 \mathrm{~A}$ & 3.18 & 12.5 & 2.11 & 19.4 \\
\hline $\mathrm{SM} 570$ & 3.26 & 13.7 & 3.37 & 31.0 \\
\hline
\end{tabular}

Note: $\Delta_{n}=$ ネッキング発生から破断までの伸びの量, $\alpha=\Delta_{n} / \delta_{r}, \quad \delta_{r}=$ 破断までの全体の変位

ているということが考えられる。.またこの角度は試験片 設計時の塑性変形部に，載荷軸方向と垂直な方向に与え た角度と概ね一致する。 今回の実験では，この角度につ いての違いは2パターンしかないため, 破断面の角度に 与える影響は今後も検討の余地がある.

\section{c) ネッキング後の伸び}

表-5にネッキング後の伸びの量 $\Delta_{n}$ （破断時の変位か らネッキング発生時の変位を差し引いたもの）とその割 合 $\alpha$ について示す．今回の試験片では，破断までの全体 の伸び $\delta_{r}$ に対するネッキング後の伸びの割合 $\alpha$ が最も大 きかった鋼種はSM570であり，その中でもST-SM570-M が31\%を占め最も大きかった，反対に最も小さかった鋼 種はSS400であり，その中でもPS-SS400-Mが11\%と最も 小さかった. このため, 今回使用した鋼種の中で, ネッ キング後の延性はSM570が良いと評価できる. 反対に, ネッキング前の伸びの割合はSS400が最も大きかった。

\section{（2）荷重一変位曲線}

実験より得られた荷重一変位曲線を図-7に示す。図-7 を用いて降伏荷重 $P_{y}$, 降伏変位 $\delta_{y}$, 最大荷重 $P_{u}$, 最大荷 重時の変位 $\delta_{u}$, 破断時の荷重 $P_{r}$, 破断時の変位 $\delta_{r}$ を決定 した，降伏点が明確でなかったため，図-8に示す手法 ${ }^{9}$ を用いて降伏荷重 $P_{y}$ および降伏変位 $\delta_{y}$ を決定した。まず 明らかに弾性域内と判断される載荷初期段階の岡性 $K_{e}$ を 実験データより算出し，その1/3を接線剛性として持つ点 の荷重を $P_{y}$, その点の変位を $\delta_{y}$ と決定した. 最大荷重 $P_{u}$ は実験のプロットデータより最も大きい荷重を採用し，
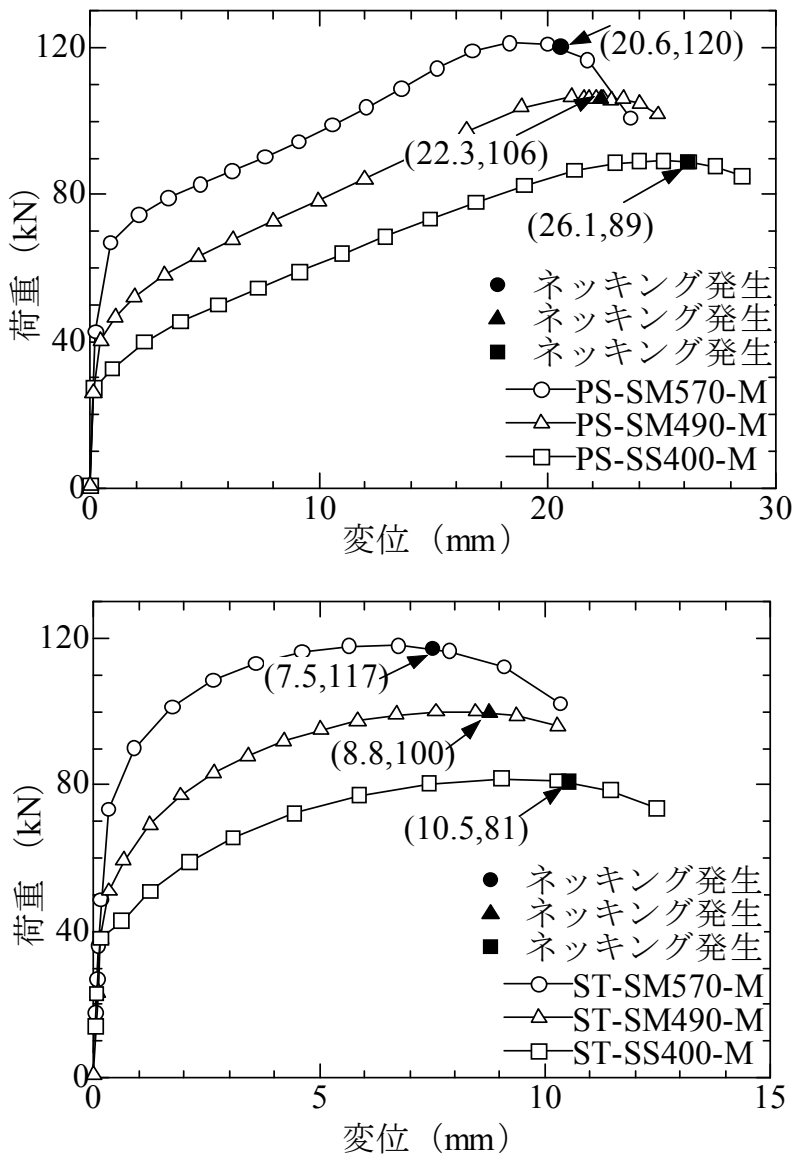

図-7 荷重一変位曲線

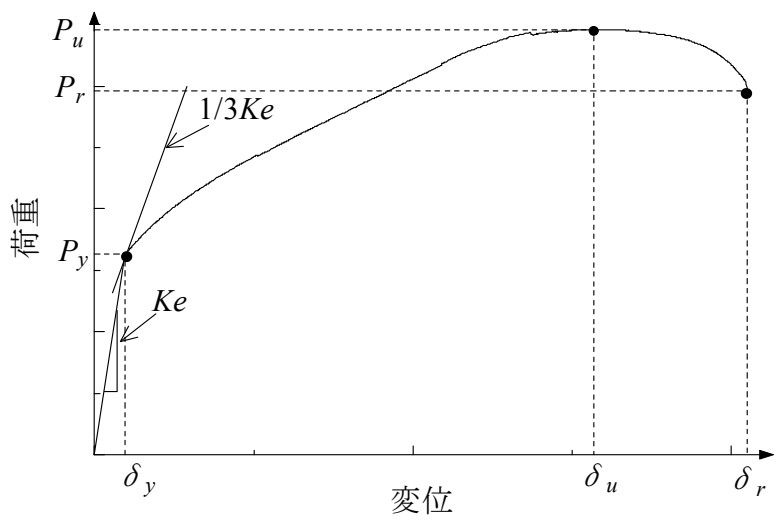

図-8＼cjkstart降伏荷重と降伏変位の決定方法 
表-6 荷重一変位曲線より得られたデータ

\begin{tabular}{|c|c|c|c|c|c|c|c|c|c|c|c|c|}
\hline \multirow{2}{*}{ 鋼種 } & \multicolumn{6}{|c|}{ PSシリーズ } & \multicolumn{6}{|c|}{ STシリーズ } \\
\hline & $P_{y}$ & $\delta_{y}$ & $P_{u}$ & $\delta_{u}$ & $P_{r}$ & $\delta_{r}$ & $P_{y}$ & $\delta_{y}$ & $P_{u}$ & $\delta_{u}$ & $P_{r}$ & $\delta_{r}$ \\
\hline SS400 & 29 & 0.16 & 89 & 24.56 & 79 & 29.40 & 37 & 0.13 & 82 & 9.00 & 72 & 12.69 \\
\hline SM490A & 36 & 0.20 & 107 & 20.63 & 96 & 25.53 & 45 & 0.19 & 100 & 8.04 & 91 & 10.88 \\
\hline SM570 & 61 & 0.43 & 121 & 18.90 & 97 & 23.85 & 71 & 0.29 & 118 & 6.45 & 93 & 10.88 \\
\hline
\end{tabular}

Note: $P_{y}=$ 降伏荷重, $\delta_{y}=$ 降伏変位, $P_{u}=$ 最大荷重, $\delta_{u}=$ 最大荷重時の変位, $P_{r}=$ 破断時の荷重, $\delta_{r}=$ 破断時の変位

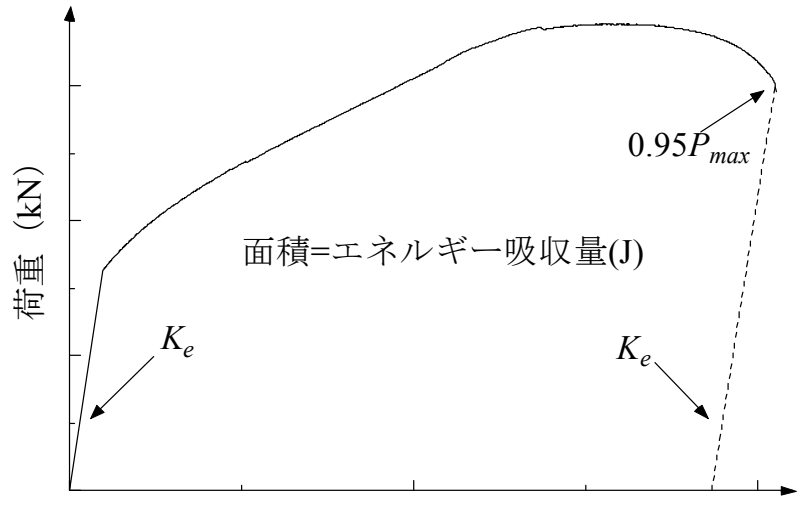

変位 $(\mathrm{mm})$

図-9 エネルギー吸収量算出方法

表-7 エネルギー吸収量

\begin{tabular}{|c|c|c|c|}
\hline 鋼種 & $\begin{array}{c}E_{P S} \\
(\mathrm{~J})\end{array}$ & $\begin{array}{c}E_{S T} \\
(\mathrm{~J})\end{array}$ & $\beta$ \\
\hline $\mathrm{SS} 400$ & 2,009 & 893 & 2.2 \\
\hline $\mathrm{SM} 490 \mathrm{~A}$ & 2,043 & 949 & 2.2 \\
\hline $\mathrm{SM} 570$ & 2,348 & 1,155 & 2.0 \\
\hline
\end{tabular}

Note: $E_{P S}=\mathrm{PS}$ シリーズのエネルギー吸収量, $E_{S T}=\mathrm{ST}$ シリ

一ズのエネルギー吸収量, $\beta=E_{P S} E_{S T}$

その時の変位を $\delta_{u}$ とした. 破断時の荷重 $P_{r}$ は荷重が一気 に低下した点の直前の荷重を採用し，その時の変位を $\delta_{r}$ とした。 これによって得られた值を表-6に示す.

表-6に示寸ように今回使用した全ての鋼種において, $P_{y}$ の值はSTシリーズの方が大きいが， $P_{u}$ の值はPSシリ 一ズの方が大きいということがわかる．また，両方のシ リーズにおいて高強度鋼であるほど $P_{u}$ の值は大きく， $\delta_{u}$ は小さな值が得られた．さらに， $\delta_{r}$ の值はPSシリーズの 方が大きく，その中でも最も大きかった鋼種はSS400で あった。これは，PSシリーズでは塑性変形部の中央部 付近は主にせん断を受けるが，その前後の部分は曲げを 主に受けるため, 塑性変形部全体で塑性変形した。 これ に対し，STシリーズでは中央部付近のみが塑性化した。 このため, 塑性化部分の大きいPSシリーズの方が $\delta_{r}$ の值 が大きくなったと考えられる。ここで，SM490A と SM570の $\delta_{r}$ は近い值が得られた。これは，ネッキング発 生までの伸びはSM490Aの方が大きかったが，ネッキン グ発生後の伸びはSM570の方が大きかったため, 最終的 な伸びは近い值が得られたと考えられる．特にSTシリ
ーズでは， $\delta_{r}$ の值はPSシリーズよりとても小さいため, 非常に近い值が得られたと考えられる.

\section{(3) エネルギ一吸収量による比較}

先に示した荷重一変位曲線を用いてエネルギ一吸収量 を算出する．図-9に算出方法 ${ }^{10)}$ を示す，実験開始から荷 重が最大荷重の $95 \%$ に低下した点までの荷重一変位曲線 を用い ${ }^{11)}$ ，この点から弾性除荷を仮定して得られた眓形 の総面積をエネルギー吸収量として算出する。その結果 を表-7に示す.ここに，両シリーズにおいて高強度鋼で あるほどエネルギ一吸収量は大きくなっていることがわ かる.これは破断時の変位は強度が高いほど小さくなる が，最大荷重が大きくなっているためであると考えられ る.また，PSシリーズはSTシリーズの概ね2倍のエネル

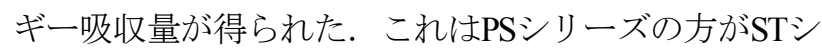
リーズより破断時の変位と最大荷重ともに大きかったた めである.

\section{4. 解析概要}

\section{(1) 解析モデル}

本解析は，実験のみでは判断が難しい載荷中の試験 片の応力状態を解明するために行った. 解析モデルを図 -10 に示す. 解析は汎用構造解析ソフト ABAQUS ${ }^{12)}$ を用 い，モデルは試験片の僅かな非対称性を考慮するためソ リッド要素にて実際の試験片のサイズで作成した。塑性 変形部は細かい要素（最大特性長さ $2 \mathrm{~mm}$ ）で分割し， その他の部分は計算時間の効率化のため粗い要素で分割 した。試験片の底部は固定し，頂部に強制変位を与える ことで実験を模擬している。また，ABAQUS explicitを用 いて慣性力の影響を無視し，準静的と判断できる程度 （全体のエネルギーと動的エネルギーの比が 5\%以内） に収めながら解析を行い, 破壊現象をシミュレーション した.

\section{（2）延性破壊モデルと応カーひずみ関係}

今回用いた延性破壊モデルは，文献13)で提案されて いるものである.このモデルはRiceとTraceyによるボイ 


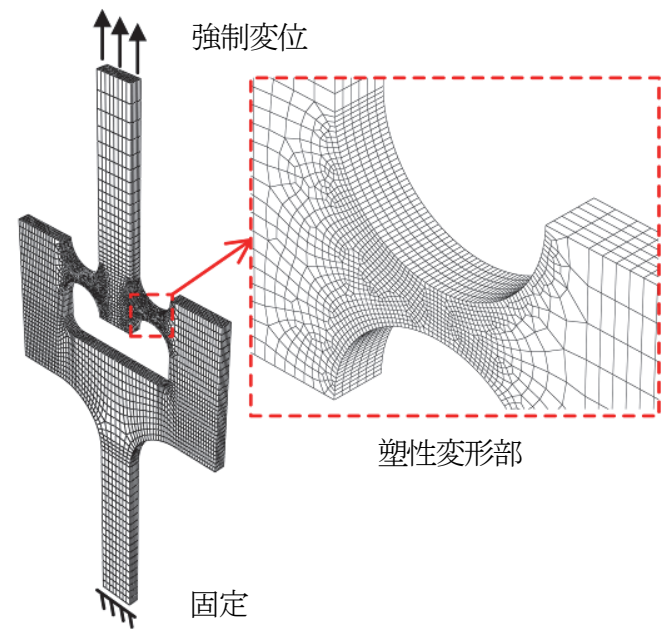

(a) PS シリーズ

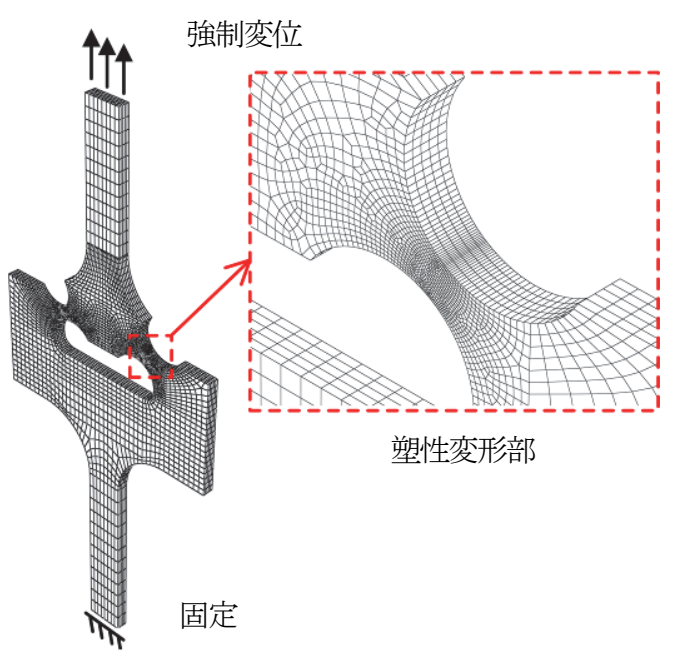

(b) ST シリーズ

図-10 解析モデル
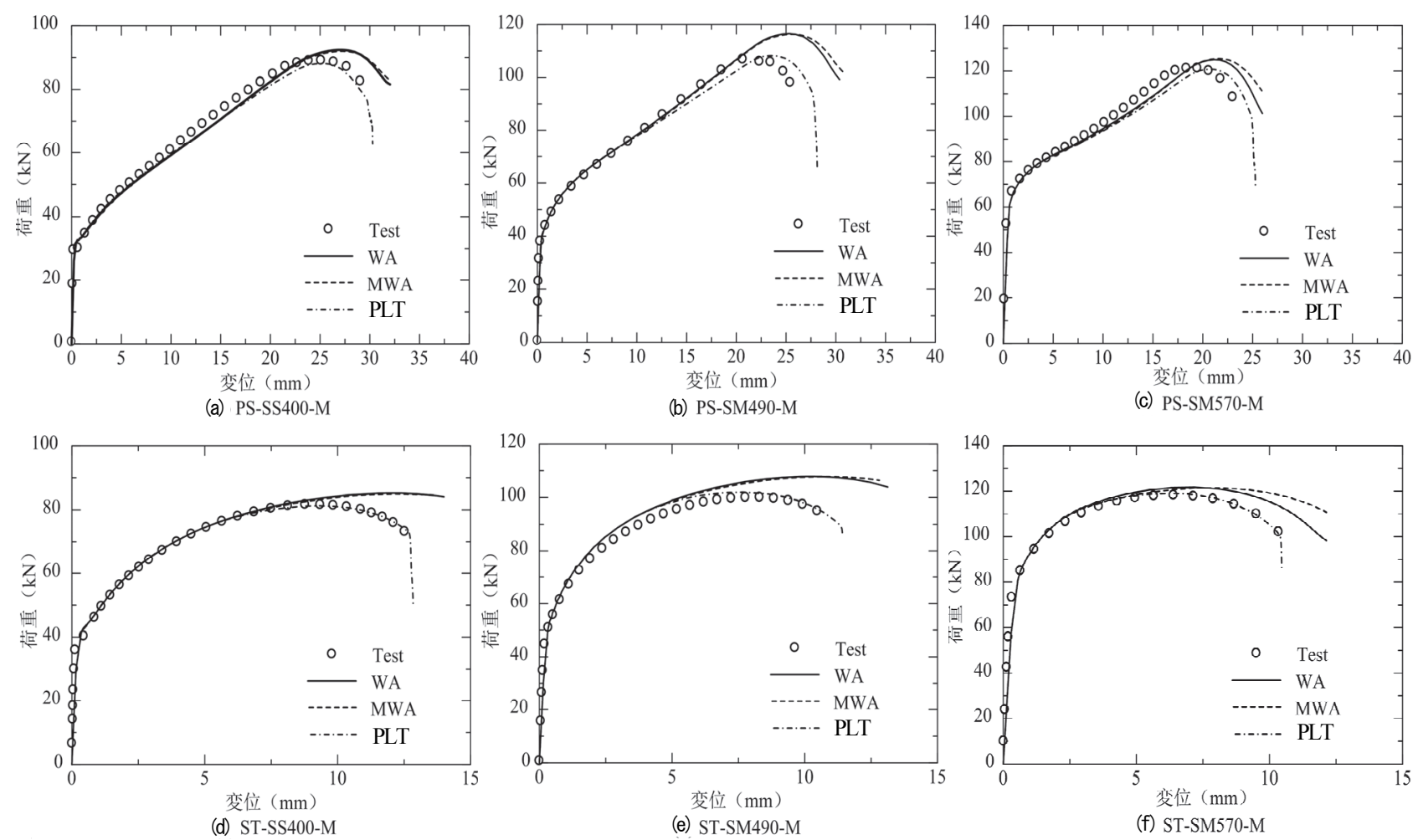

図-11 荷重一変位曲線の比較

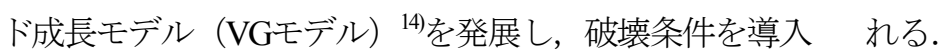

している．応力三軸度 $T$ （静水圧応力 $\sigma_{m}$ と等価ミーゼス 応力 $\sigma_{e q}$ の比）が一定であると仮定すると，破壊ひずみ $\varepsilon_{f}$ と応力三軸度 $T$ との関係は次の式で表される.

$$
\varepsilon_{f}=\ln \frac{R_{f}}{R_{0}} /\left(0.283 e^{\frac{3}{2} T}\right)=\chi \cdot e^{-\frac{3}{2} T}
$$

ここで, $R_{f}=$ 破壊時のボイドの等価半径， $R_{0}=$ ボイドの 初期半径, $\chi=R_{f}$ と $R_{0}$ の比による破壊パラメータである. しかし，応力三軸度 $T$ は実際には載荷中常に，連続的に 変化するため, 損傷指数 $D$ を微小増分で表し, 微小増分 内での応力三軸度を一定とすると, $\mathrm{d} D$ は次の式で表さ

$$
\mathrm{d} D=\frac{\mathrm{d} \varepsilon_{e q}^{p}}{\varepsilon_{f}^{p}(T)}=\frac{\mathrm{d} \varepsilon_{e q}^{p}}{\chi \cdot e^{-\frac{3}{2} T}}
$$

ここで, $\mathrm{d} \varepsilon_{e q}^{p}=$ 相当塑性ひずみの増分である. 異なる忘 力三軸度下で，損傷が線形であるとして $D$ が 1 に達し たとき破壊するとした.

応力ーひずみ関係については，既往の方法（WA, MWA 法) 13),15)では，一軸引張の材料試験から得られた 公称応力一公称ひずみ曲線を真応力一真ひずみ曲線に換 算しているが，ネッキング後の真応力を一致させるのが 難しいため, 図-11 に示すようにネッキング以降の荷重 
が過大評価されてしまった。 そこで，ネッキング後の荷 重一変位曲線を精度よくシミュレーションするため, 真 応力ー真ひずみ関係は次に示寸手法 (Power Law Tangent 法，以降PLT法と称する）を用いて求める.

ネッキング発生までは，これまでのように公称応力一 公称ひずみ曲線から真応力一真ひずみ曲線を定めるが,

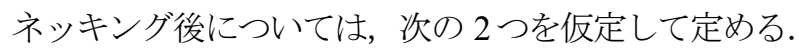

1) ネッキング後の硬化率（真応力一真ひずみ曲線の傾 き）は指数則に従う．2）ネッキング発生後の硬化率は次 第に減少する．これにより，ネッキング後の真応力一真 ひず夕関係の傾きを次のように定義することができる.

$$
\frac{\mathrm{d} \sigma}{\mathrm{d} \varepsilon}=\sigma_{\text {neck }} \cdot\left[1-\left(\varepsilon-\varepsilon_{\text {neck }}\right)^{n}\right]
$$

ここで, $n$ は硬化率の減少速度によって決定される材料 パラメータであるが, 引張試験の結果から SS400,

SM490A および SM570 の場合， $n$ はそれぞれ $0.50,0.35$ および 0.32 と決定されている ${ }^{13)}$.

したがって，ネッキング前の真応力一真ひずみ曲線は 指数則に従うものとし，またネッキング後は式(3)を積 分することにより, 次式が得られる.

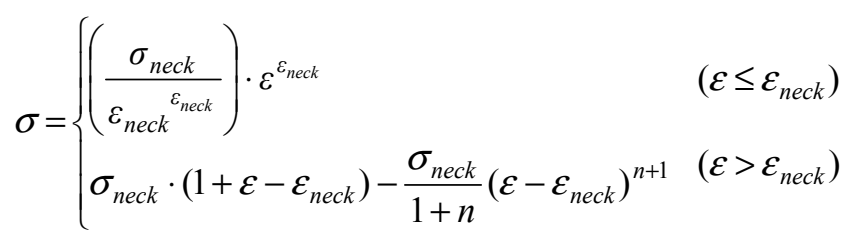

図-11 より，WA 法と MWA 法に比べ，PLT 法を用いる と ST シリーズではとても精度よく荷重一変位曲線を一 致させることができた. PS シリーズでも概ね一致して いる，これにより，本手法の妥当性を示すことができた，

\section{5. 解析結果}

\section{（1）破壊状況と塑性相当ひずみ}

初めに，試験片の破壊状況と相当塑性ひずみの最大值 を図-12 に示寸。これにより実験での試験片の僅かな非 対称性が破壊状況に及ぼす影響を概ね再現できたといえ る．また，破断面の角度を同じように表示したところ， 表-4 に示すように実験と同様 PS シリーズでは概ね $0^{\circ}$, ST シリーズでは概ね $30^{\circ}$ の角度が得られた。 さらに，図 -12 の色の濃くなっている部分はひずみ集中を受ける部 分であり, ネッキング後この部分には計測した角度をも ってひずみが集中したことが考えられる.ただし，この 角度は設計時の角度に依存寸ることに注意されたい。

\section{（2）応力三軸度と塑性相当ひずみ}

次に, 応力三軸度 $T$ と相当塑性ひずみ $\varepsilon_{e q}^{p}$ の関係につ

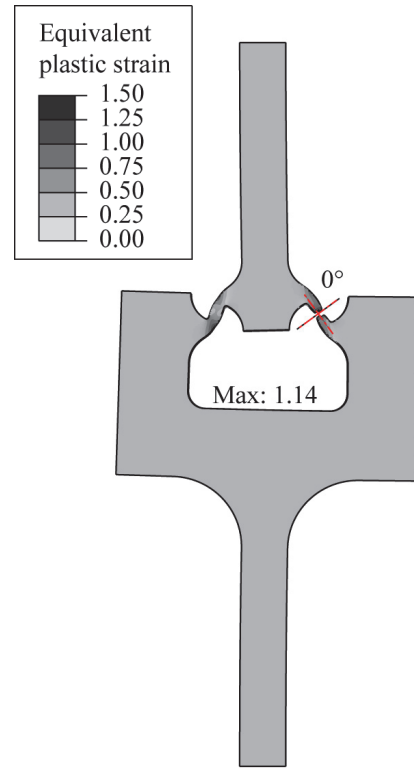

(a) PS-SM490-M

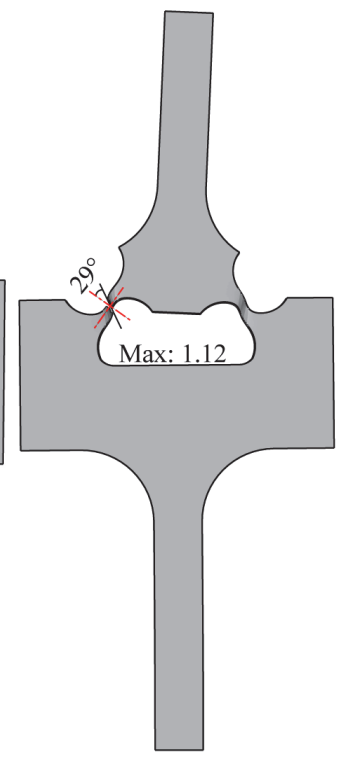

(b) ST-SM490-M
図-12 破壊状況と相当塑性ひずみ

いて図-13 に示寸. 図-13 において, 引張試験片の結果 を見てみると, ネッキング発生前は全ての鋼種において 応力三軸度は 0.33 であった. これが示すのはネッキン グ発生までは一軸引張が支配した応力状態ということで ある. その後, 局所的な変形のため応力三軸度は増大し た．PS シリーズでは全ての鋼種で同じような曲線が見 られ，相当塑性ひずみが 0.16 より小さいとき応力三軸 度はほとんど 0.0 であった. このため, 塑性変形部中央 ではせん断応力が支配的であるとわかる．また，相当塑 性ひずみが 0.16 から 0.3 の範囲では応力三軸度は急激に 増大し， 0.3 を超えると直線的に上昇した. ST シリーズ については，相当塑性ひずみが 0.0 から 0.2 の範囲では 応力三軸度は 0.1 から 0.4 まで急激に増大し, せん断応 力が支配的であることがわかる. また, 相当塑性ひずみ が 0.2 を超えると直線的に上昇した. これにより, 載荷 初期段階では両シリーズともせん断応力が支配的である ことを示すことができた.

\section{（3）損傷指数と塑性相当ひずみ}

さらに，損傷指数 $D$ と相当塑性ひずみ $\varepsilon_{e q}^{p}$ の関係を 図-14 に示す.これは解析により最も早く損傷指数が 1 に達した要素の結果である.引張試験片と PS シリーズ, ST シリーズの解析結果をネッキング発生時の值と共に 示寸. 図-6の引張試験片の結果を見ると全ての鋼種に おいて, ネッキング前の変形が大部分を占めていること が明らかであるが，図-13 の損傷指数に注目するとネッ キング前ではごく僅かしか累積していないことがわかる. 同様に図-7 を見ると PS シリーズでもネッキング前の変 形が大部分を占めており，ネッキング前の損傷指数は SS400, SM490A，SM570 の順に 25\%，19\%，19\%であり， 


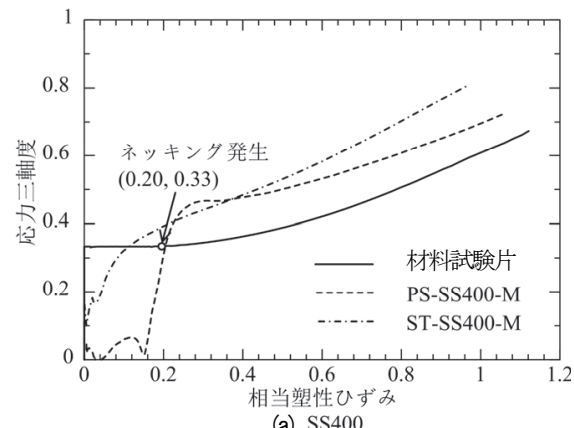

(a) SS400

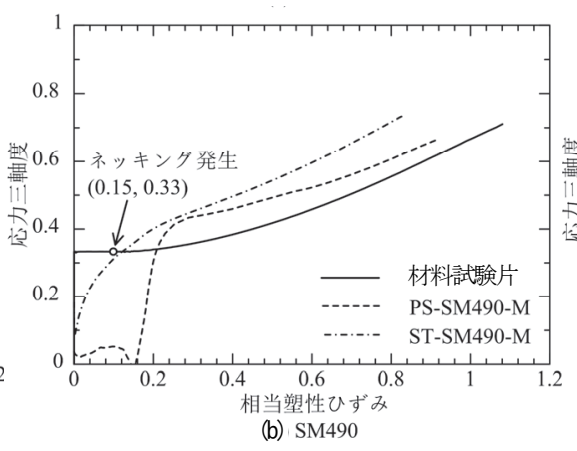

(b), SM490

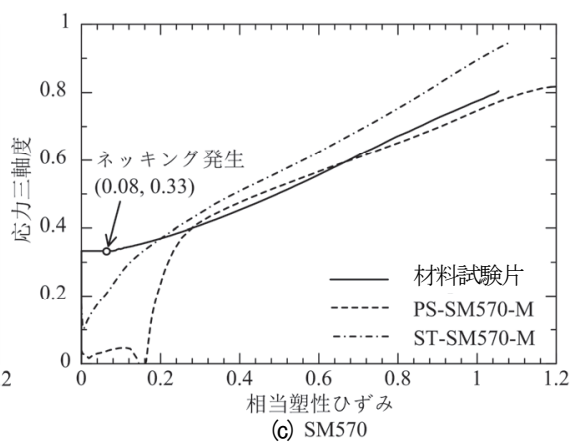

図-13 応力三軸度と相当塑性ひずみの関係

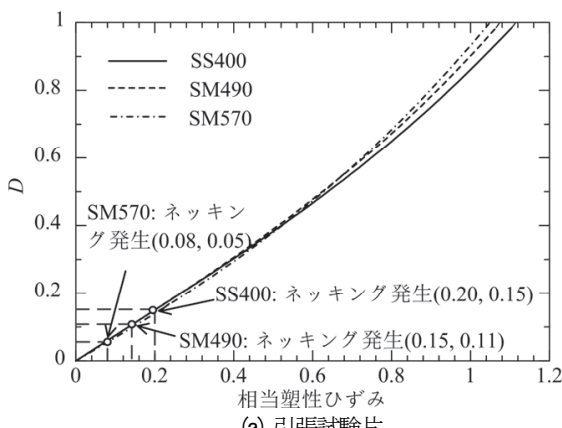

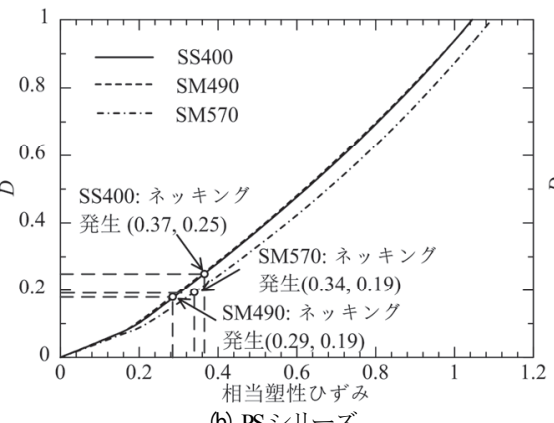

(b) PSシリーズ

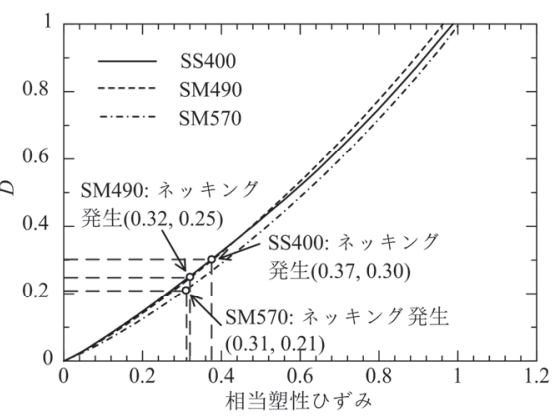

(c) STシリーズ

図-14 損傷指数と相当塑性ひずみの関係

大部分の損傷はネッキング以降であるといえる．同じく ST シリーズでもそれぞれ 30\%，25\%，21\%であった. こ れは, 図-11，13，14 と式(2)より，ネッキング前では, 各要素が比較的均等な変形をするため, 応力三軸度と相 当塑性ひずみの值は小さく，損傷はあまり累積しないが, ネッキング後は着目要素が僅かな変形の内に応力三軸度 と相当塑性ひずみは急激に上昇したため，損傷指数も急 激に累積した.さらに, 鋼材の強度が上がるほどネッキ ング前の損傷は小さいことがわかる.

また，図-14 より相当塑性ひずみが増大寸ると損傷指 数は概ね線形的に増加することもわかる. 寸べての試験 片において，変形に関してはネッキング前が大部分を占 めている実験結果に対し，損傷指数に関してはネッキン グ後が大部分を占めている解析結果となっている.

\section{（4）載荷中の応力状態}

最後に, パラメータ $\omega$ を用いて載荷中の応力状態に ついて検討寸る。 $\omega$ は式(5)の偏差角 $\theta$ と式(6)，(7)の不変 量 $J_{2}, J_{3}$ により，式(8)のように定義される ${ }^{10}$.

$$
\begin{aligned}
& \cos 3 \theta=\frac{27 J_{3}}{2\left(\sqrt{3 J_{2}}\right)^{3}}=\frac{27 J_{3}}{2 \sigma_{e q}^{3}} \quad\left(0 \leq \theta \leq \frac{\pi}{3}\right) \\
& J_{2}=\frac{S_{1}^{2}+S_{2}^{2}+S_{3}^{2}}{2} \\
& =\frac{1}{6}\left[\left(\sigma_{1}-\sigma_{2}\right)^{2}+\left(\sigma_{2}-\sigma_{3}\right)^{2}+\left(\sigma_{3}-\sigma_{1}\right)^{2}\right]
\end{aligned}
$$

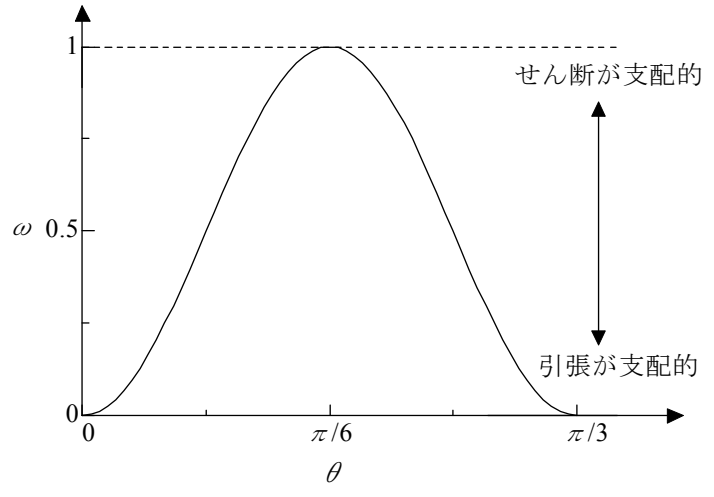

図-15 $\theta-\omega$ の関係

$$
J_{3}=S_{1} \cdot S_{2} \cdot S_{3}
$$

$$
\omega=\sin ^{2} 3 \theta \quad(0 \leq \omega \leq 1)
$$

図-15 に示すように， $\omega$ が小さいときに引張が支配する 応力状態であり， $\omega$ が大きいときにせん断が支配する応 力状態である.これをユーザー定義として ABAQUS に 書き込み, PS-SS400-M と ST-SS400-M の応力状態をプロ ットした。 その結果を図-16 に示す. PS シリーズ, ST シリーズ共に載荷初期段階における塑性変形部の中央部 では $\omega$ は概ね 1.0 であり, せん断応力が支配的であるこ とを示す.ネッキング発生直前までは $\omega$ の值は概ね 1.0 であった．しかし，ネッキングが発生すると， $\omega$ の值は 低下した. ネッキング発生後における $\omega$ は概ね 0.0 であ り，引張応力が支配的であることを示寸. 


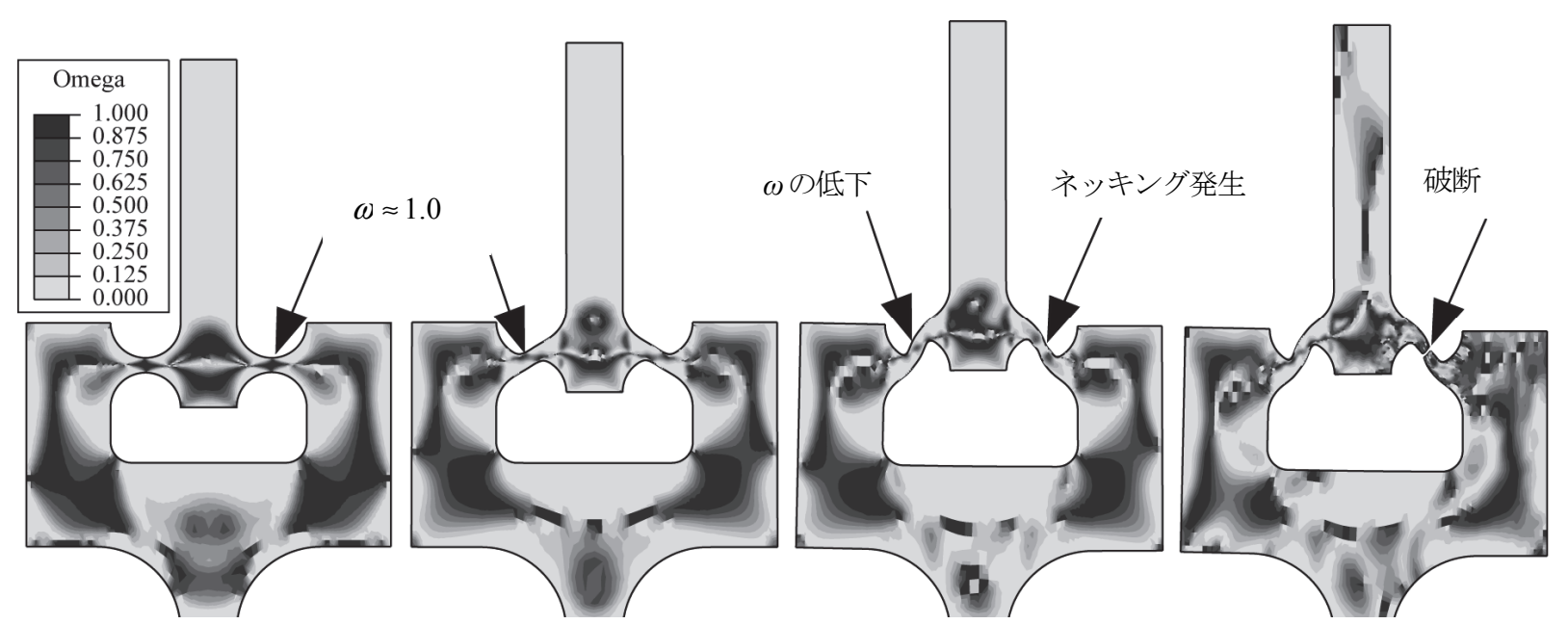

(a) PS-SS400-M
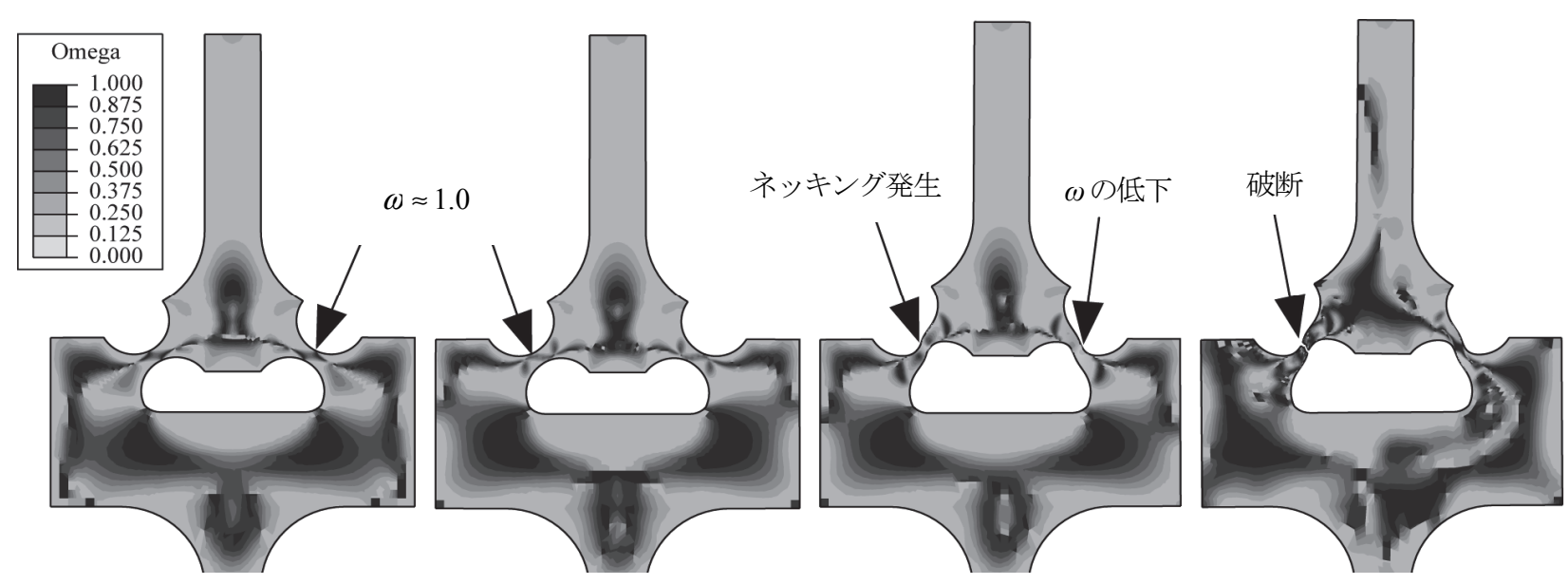

(b) ST-SS400-M

図-16 $\omega$ の推移

以上のように，実験の載荷中のせん断応力と引張応力 の状態を明らかにすることができた.

\section{6. 結言および今後の研究課題}

\section{(1) 結言}

本研究は，せん断応力と引張応力が作用する状況での 単調載荷試験による鋼材の延性破壊実験およびシミュレ ーション解析を行い，破壊モード，エネルギ一吸収量に 応力状態や鋼種の違いが与える影響などについて検討し た. 得られた主な知見を以下に示す.

1. 載荷中塑性変形を受ける過程において概ね左右対称 の変形をしたが，ネッキングは片側のみで発生しそ の部分に変形が集中し一気に破断した。試験片の設 計は左右対称であるが，ネッキング発生以降の破壊 が対称ではなかったのは僅かな試験片の非対称性や, 載荷軸の偏心が敏感に影響したためである.

2. 破断面の角度を見ると破断直前では，純せん断を仮
定したPSシリーズでは一軸引張試験の破断面と一致

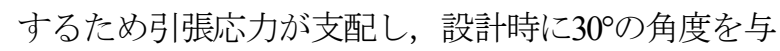
えたSTシリーズではせん断応力と引張応力が作用し たと考えられる.

3. ネッキング後の伸びの割合は今回使用した鋼種の中 でSM570が最も大きく，ネッキング後の延性が良い と評価できる. 反対にネッキング前の伸びの割合は SS400が最も大きくネッキング前の延性が良いと評価 でき，鋼材の強度が高いものほどネッキング後の延 性が良く, 低いものほどネッキング前の延性が良い といえる.

4. ネッキング前では，各要素が比較的均等な変形をす るため, 応力三軸度と相当塑性ひずみの值は小さく 損傷はあまり累積しないが，ネッキング後は着目要 素が僅かな変形の内に応力三軸度と相当塑性ひずみ は急激に上昇したため，損傷指数も急激に累積した。

5. 相当塑性ひずみがPSシリーズでは0.16, STシリーズ では0.2以下においてせん断応力が支配していたとい え， $\omega$ が示すようにネッキング発生後引張応力が占 


\section{める割合が大きくなったことを明らかにした。}

\section{(2) 今後の研究課題}

今回の研究では，塑性変形部に与えた角度は2パター ンのみであったためパターンを増やして検討することが 必要である，そして，載荷パターンの違いによる影響を 検討するため繰り返し載荷での実験を行う必要がある. また，純せん断が作用すると仮定したPSシリーズが塑 性変形を受ける過程で引張応力が支配してしまったため, 載荷中常にせん断応力のみが作用する試験片のモデルを 検討する必要がある.

謝辞：本研究は，平成24年度に採択された科学研究費補 助金・基盤研究 $(C)$ (研究代表者 : 葛 漢涁; 課題番 号 : 24560588) および平成24年度私立大学戦略的基盤研 究形成支援事業「21世紀型自然災害のリスク軽減に関す るプロジェクト」で名城大学に設置された「自然災害リ スク軽減研究センター」の助成を受けて実施されたもの である。

\section{参考文献}

1) 岡下勝彦，大南亮一，道場康二，山本晃久, 冨松実, 丹治康行，三木千壽 : 兵庫県南部地震による神戸港 港湾幹線道路 P75 橋脚隅角部におけるき裂損傷の原 因調査・検討，土木学会論文集，No.591/I-43， pp.243-261, 1998.

2) 佐々木栄一，荒川泰二，三木千壽，市川篤司：鋼製 橋脚における地震時脆性破壊防止に必要な鋼材の破 壊靭性レベル，土木学会論文集，No.731/I-63，pp.93102, 2003.

3) 羽田新輝, 速水景, 鈴木俊光, 葛漢涁 : ルートギャ ップが存在する鋼厚肉部材の未溶着高さおよびフィ レット半径の違いによる延性き裂発生・進展への影 響に関する実験的研究, 土木学会中部支部平成 23 年 度研究発表会, I-10, pp.19-20, 2012.

4) 橋田知幸, 藤平正一郎, 南二三吉, 豊田政男：兵庫 県南部地震による被害鉄骨仕口部の強度・鞋性変化
特性, 日本建築学会大会学術講演梗概 C-1 構造III, pp.859-860, 1996.

5) 天野麻衣, 渡辺智彦, 宇佐美勉, 葛漢涁 : 繰り返し せん断力を受ける鋼板の強度と変形能, 土木学会,

第 3 回鋼構造物の非線形数值解析と耐震設計一の応 用に関する論文集，pp.57-62，2000.

6) 葛漢涁, 大橋正稔, 田島僚 : 鋼製厚肉断面橋脚にお ける延性き裂の発生とその進展に関する実験的研究, 構造工学論文集, Vol.53A, pp.493-502, 2007.

7) 鈴木敏郎, 五十嵐規矩夫, 常木康弘: H 形鋼梁ウエ ブ板要素の弾塑性せん断座屈挙動に関する研究, 日 本建築学会構造系論文集, No.556, pp.151-158, 2002.

8) 奈良敬, 出口恭司, 福本唀士 : 純せん断応力を受け る鋼板の極限強度特性に関する研究，土木学会論文 集, No.392, pp.265-271, 1988.

9）島田侑子, 吉敷祥一, 山田哲: 実験結果に基づく全 塑性モーメントの評価方法に関する考察, 日本建築 学会関東支部研究報告集, No.2042, pp.305-306, 2008.

10）原田浩之, 江頭寛, 小田稔, 小坂英之, 山中久幸： 軸ひずみを有する低降伏点鋼制震パネルのせん断加 力実験, 日本建築学会大会学術講演梗概集, No.21265, pp.529-530, 2008.

11) 宇佐美勉, 織田博孝 : 鋼構造物の耐震解析法および 耐震照査法に関する研究展望, 土木学会論文集, No.668/I-54, pp.1-16, 2001.

12) ABAQUS/Standard Manual(version 6.10), Hibbitt, Karlsson \&Sorensen, Pawtucket, RI., 2010.

13) Jia, L. J. and Kuwamura, H: Ductile fracture simulation of structural steels under monotonic tension, Journal of Structural Engineering, ASCE, Vol.140, No.5, 2014(doi: 10.1061/(ASCE)ST.1943-541X.0000944).

14) Rice, J. R. and Tracey, D. M.: On the ductile enlargementof voids in triaxial stress fields, J. Mech. Phys. Solids, Vol.17, No.3, pp.201-217, 1969.

15) Ling, Y.: Uniaxial true stress-strain after necking, AMP Journal of Technology, Vol.5, pp.37-48, 1996.

16) Nahshon, K. and Hutchinson, J. W.: Modification of the Gurson model for shear failure, European Journal of Mechanics A/Solids, Vol.27, pp.1-17, 2008.

(2014. 11. 11受付, 2015.1.28修正, 2015. 2. 21受理)

\section{A STUDY ON DUCTILE FRACTURE MECHANISM OF STRUCTURAL STEELS UNDER COMBINED SHEAR AND TENSILE STRESSES}

\section{Kazuki SHINOHARA, Liang-Jiu JIA, Hiromu KATO and Hanbin GE}

Fracture of fillet welds and partial penetration welds was observed in past strong earthquakes, where the location of crack initiation is subjected to combined shear and tensile stresses. However, studies on ductile fracture under the coupling stress state are limited in the field of steel structures. This study aims to experimentally and numericaly investigate the effect of coupling stress on ductile crack initiation and propagation of several typical steels in bridge engineering. Two series of specimens made of three different steels are employed, where specimens are respectively under pure shear, shear and tension at the initial loading stage. The cracking processes of the specimens are studied. Meanwhile, absorbed plastic energy of the specimens is also investigated. 